UDC 622.1:622.83+622.35

DOI: https://doi.org/10.26642/tn-2018-2(82)-259-267

V. Levytskyi, PhD

A. Makhno, M.S.

A. Panasiuk, PhD

V. Mamrai, M.S.

Zhytomyr State Technological University

\title{
Dimension stone blocks modelling based on digital surface model methods
}

The size and shape of natural stone parts, that are defining the rock jointings, are also affecting mining technology and field of operations. Besides, it influences monolith optimal cutting scheme for commercial dimension stone blocks, corresponds to required geometrical dimensions. Prediction and selection of rational ways of cutting structural blocks is really important issue, because stone losses depend on the cutting pattern and also further inaccuracies in measuring the size of commercial blocks due to different factors. The main problem in this field is improving the accuracy of measuring the size of block at the dimension stone quarries which is based on the simulation of natural individualities and the introduction of indirect methods for determining the qualitative and quantitative characteristics of commercial blocks. The main factors that can cause the accuracy of determining the commercial blocks volumes under traditional methods of their calculation are also considered in this work. The authors analyzed the main indexes of the commercial block passport, as well as the possibility of adjusting the individual technological parameters for the separation of monoliths into blocks. Classification of block products is proposed for classes depending on qualitative indicators. Possible models of the formation of the basic parameters when separating the monolith on commercial blocks are considered, as well as the formed cost component for the possibility of rapid accounting in mining enterprises.

Keywords: dimension stone; stone quarries; digital surface model; granite blocks

Introduction and formulation of the problem. In accordance with the international standards, blocks are characterized by the shape, size, volume and quality of the surface, which depends on the extraction technology. If we are taking into account the tendency to increase the volume of extraction of blocks of decorative stone, the actual determination of the commercial volume is very important for both the buyer and the seller. Measurement inaccuracy can be caused by many factors, among which there are the human factor, the roughness of the faces of the block, the volume of the block and the conditions under which the measurements are performed.

Objectives. The main goals of this article is to determine the optimal pattern of cutting monoliths of regular and irregular shapes in order to reduce stone losses and increase profits of stone-mining enterprises and also automation of selecting process the optimal cutting pattern.

Analysis of previous studies and publications. The study of the main standings of ground-based photogrammetrics was devoted to scientific works by Russian scientists Bobir M.Ya. [3], Dubinovskyi V.B. [11], Lobanov O.M. [10, 11] and Ukrainian scientists Mogilnyi S.G. [12], Sobolevskyi R.V. [9, 20-22], Dolgikh O.V. [6], Dolgikh L.V. [5, 6].

Permanently work is ongoing on automating the process of processing images. Significant contribution to the development of digital image processing, focused on the solution of photogrammetric problems, was made by Russian scientists Gelman R.N. [4], Chibunichev O.G. [22], Knizhnikov Yu.F. [8] and others.

Problems of surveying works automation on the basis of digital photogrammetric methods were involved Dolgikh O.V. [6], Dolgikh L.V. [5, 6], Maletskyi M.M. [6], Fedorenko P.I. [21].

The obtained results show that digital image analysis method has a very good accuracy in assessing the fine structures, and also it collects data in a much shorter time [17]. A software for analyzing the geometric characteristics of fracturing in a rock mass was developed by Turanboy \& Ülker [18] and González-Aguilera [19].

Methods. Research of the linear dimensions of blocks measuring process using traditional methods made it possible to determine the main factors that affecting the accuracy of measurements and the calculation of the volume of commercial blocks. These factors include:

1. The shape and size of natural rock monoliths (jointings). The following types of jointings are characteristic of decorative stone deposits:

- parallelepiped (cubic, rhombic, prismatic) type;

- formation type;

- many-sided type.

2. The volume of the block. The relation of measurement accuracy on the volume of blocks was considered in [1].

3. Irregularities of the faces and chipped ribs of the block. Depending on the method of preparing the blocks for excavation, all blocks are divided into two groups - splitted and sawn. For these two groups, the standard 
deviation values are determined (table 1), which are required to be adhered to both in assessing the quality of the blocks and in measuring their sizes [2].

Surface of decorative rock blocks quality requirements

\begin{tabular}{|c|c|c|c|c|}
\hline \multirow{2}{*}{ Indicators } & \multicolumn{2}{|c|}{ Splitted by groups } & \multicolumn{2}{|c|}{ Sawn by groups } \\
\hline & I-III & IV-VI & I-III & IV-VI \\
\hline $\begin{array}{l}\text { The deviation from the perpendicularity of } \\
\text { two adjacent faces per } 1 \mathrm{~m} \text { of the height of the } \\
\text { face, } \mathrm{mm}\end{array}$ & $\leq 60$ & $\leq 60$ & $\leq 110$ & $\leq 110$ \\
\hline Depth of the block contours, $\mathrm{mm}$ & $\leq 150$ & $\leq 100$ & $\leq 150$ & $\leq 150$ \\
\hline $\begin{array}{l}\text { The height of the ledges and the depth of the } \\
\text { depressions in the maximal gap under the } \\
\text { ruler, mm: } \\
\text { for top and bottom faces } \\
\text { for other faces }\end{array}$ & $\begin{array}{l}\leq 100 \\
\leq 150\end{array}$ & $\begin{array}{l}\leq 40 \\
\leq 100\end{array}$ & $\begin{array}{l}\leq 100 \\
\leq 200\end{array}$ & $\begin{array}{l}\leq 100 \\
\leq 100\end{array}$ \\
\hline The number of reflected angles & $\leq 3$ & $\leq 3$ & $\leq 3$ & $\leq 3$ \\
\hline $\begin{array}{l}\text { The splitting line length of reflected angle } \\
\text { along the edge of the block, mm }\end{array}$ & $\leq 150$ & $\leq 60$ & $\leq 200$ & $\leq 80$ \\
\hline $\begin{array}{l}\text { The total length of the splitting line of } 1 \mathrm{~m} \\
\text { edges block, mm }\end{array}$ & $\leq 150$ & $\leq 150$ & $\leq 200$ & $\leq 300$ \\
\hline
\end{tabular}

4. The human factor. As a result of inaccuracies in the application of dimensional tools and the correct choice of two points on one face of a block to find the distance between them by net dimensions, an error occurs in measuring the linear dimensions of a block.

5. The temperature at which the measurement is carried out. The effect of temperature on the stretching or compression of a measuring instrument is characterized by a correction coefficient for thermal expansion.

The determining factor for creating the optimal pattern of cutting natural monoliths is their shape and size.

Studies have shown that a directly proportional relationship is observed between the actual volume of a block and the errors in determining the commercial volume, as well as economic losses for different types of deposits of a decorative stone.

Up to this day the calculation of the useful volume of the block is carried out according to its net dimensions, and this leads to an overestimation of prices for block products, unreliable calculations of raw materials for the manufacture of finished products, degradation of their quality. And also the net volume of blocks does not take into account the technological impact of mining blocks on their quality.

Modern technical equipment (theodolites, electronic tachometers), electronic and registration methods and digital measurement processing made it possible to develop and conduct research on the method of determining the volume of commercial blocks of a decorative stone, which is based on creating a spatial formed model using reference points defined in the conventional coordinate system. The use of this technique minimizes the disadvantages of the traditional method of determining the volume of a block (improves accuracy) and allows us to create a product block passport based on the obtained data.

The passport of the commercial blocks will be included in the official mine survey documentation for the quarry monolith blocks, for which the main surveyor will maintain and update. The passport contains the following information: digital image of the block, spatial 3D model of the block, commercial, gross and net block volumes, group and quality class of the block [3], coordinates of reference points, description of technical means (theodolite, digital camera) for land-based surveying of the block, the main parameters of the survey, the accuracy of determining the volume of the commercial block, as well as the presence of defects and some technological parameters (output of slabs, the optimal direction of sawing).

It should be also noted that the indicator of the quality class of block monoliths is introduced in order to systematize and divide the blocks into four classes with respect to the gross dimensions and the commercial dimensions of the block and the presence of defects, which further makes it possible to predict the output of finished products. Blocks are divided into the following quality classes:

- class «A» - the difference between gross and commercial volume is up to $15 \%$; no defects (inclusions, cracks, changes of shade);

- class $\langle\mathrm{B} »-$ the difference between gross and commercial volume is up to $30 \%$; some defects on the surface;

- class $\langle\mathrm{C} »-$ the difference between gross volume and commercial volume up to $50 \%$; There are some penetrating defects, but they are not taken into account when measuring a block, because they are assigned to an ineffective volume. 
- class $\langle\mathrm{D} »-$ the difference between gross volume and commercial volume more than $50 \%$; There are some penetrating defects (cracks, inclusions, color changes).

The effectiveness of measurement work and periodic replenishment of graphic surveying documentation can be increased by using modern computer technologies, digital cameras to obtain information about the object of study and its subsequent processing. Therefore, the introduction of digital photogrammetric methods at decorative stone quarries, which can satisfy a given accuracy, is an important task, one of the ways to solve which is the use of terrestrial stereo-photometric recording with high-precision surveying instruments and digital cameras.

So we can model the main parameters for cutting monoliths into commercial blocks, taking into account the following limitations:

1. The linear dimensions of the blocks should, in approximation, correspond to the size of trolleys for rock cutting machines:

$$
b \leq b_{1} ; h \leq h_{1} ; l \leq l_{1},
$$

where $b, h, l$ are respectively, the width, height and length of the block, $\mathrm{m} ; b_{1}, l_{1}$ are respectively, the width, height and length of the receiving frame of the trolley, $\mathrm{m} ; h_{1}$ is the vertical distance between the trolley and the frame of the rock cutting machine, $\mathrm{m}$.

2. The weight of the block must ensure the possibility of loading it with a crane into the automobile transport:

$$
Q_{b l} \leq Q_{\kappa} \text {, }
$$

where $Q_{b l}$ is block weight, t; $Q_{\kappa}$ is crane capacity, t.

When we creating an economic-mathematical model for cutting a monolith, we assume that $n$ monoliths with a volume $V_{M}$ can be used to obtain $n$ block sizes from a monolith $\zeta_{j}(j=1, n)$. Let's say $V_{j}$ is the volume of block number $j$. It is required to find the scheme of layouts $\left(x_{1}, x_{2}, \ldots, x_{n}\right)$ in which there profit $F$ from the sale of the received blocks and profit from the sale $c_{j}$ block number $j$ are maximal.

The model of the task is:

$$
\max F=\sum_{j=1}^{n} c_{j} x_{j},
$$

- with monolith volume limits:

$$
\sum_{j=1}^{n} V_{j} x_{j} \leq V_{\mathcal{M}} \text {. }
$$

- condition of non-negative: $x_{j} \geq 0, c_{j} \geq 0$.

- integer condition: $x_{j}$ is integral.

Profit from the sale $c_{j}$ of the $j$-th block can be determined using the equation:

$$
c_{j}=B_{j}-S_{j}
$$

where $B_{j}$ is market price of the $j$-th block, $\$ ; S_{j}$ is cost of production the block, $\$$.

The cost of production block unit (excluding the cost of mining and transport works) consists of the following components:

$$
S_{j}=\left[A_{p} \cdot f_{p}+A_{\kappa} \cdot f_{\kappa}+\frac{C_{2 . n}}{K_{u}}\right] \cdot V_{j},
$$

where $A_{p}$ and $A_{\kappa}$ are the cost of exposure of $1 \mathrm{~m}^{2}$ of the surface of the deposit, respectively, cutting and splitting $\$ / \mathrm{M}^{2} ; f_{p}$ and $f_{\kappa}$ is specific area of exposure to cutting and splitting (per $1 \mathrm{~m}^{3}$ of the deposit), $\mathrm{m}^{2} / \mathrm{m}^{3} ; C_{2 . n}$. is costs of mining preparatory work (per $1 \mathrm{~m}^{3}$ of the deposit), $\$ ; K_{u}$ is blocks output ratio.

After substituting into equations (5), (6) in (3) we get:

$$
\max F=\sum_{j=1}^{n} x_{j} \cdot\left(B_{j}-\left[A_{p} \cdot f_{p}+A_{\kappa} \cdot f_{\kappa}+\frac{C_{2 . n}}{K_{u}}\right] \cdot V_{j}\right) \text {. }
$$

Thus, the optimization of the process of cutting the monolith consists of choosing such a sequence of edges of a directed graph, which ensures a minimum of operating costs. The economic-mathematical model (1-8) is linear. Managed variables are all indicators that take non-negative values. Thus, the developed economic-mathematical model for cutting the monolith satisfies the conditions of the general linear programming problem. 
To determine the output rate of $K_{u}$ blocks, we use the method of estimating the blockings by prof. N.T. Bakka [4], [5], the essence of which is to create models of natural blocks based on a detailed study of fracturing in a specific area of the field and comparing natural and artificial blocks. In this case, the output of the blocks is considered as:

$$
K=\left(1-\frac{V_{n p}-V_{u c \kappa}}{V_{n p}}\right) \cdot 100 \% \cdot K_{o b},
$$

where $V_{n p}$ is natural block volume, $\mathrm{m}^{3} ; V_{u c k}$ is volume of artificial block, $\mathrm{m}^{3} ; K_{o b}$ is the general coefficient that takes into account the influence of all factors on the propagation of fractures in the deposit.

The volume of natural jointing can be determined using the formula:

$$
V_{n p}=d_{\mathrm{Q}} \cdot d_{S} \cdot d_{L},
$$

where $d_{Q}$ is average distance between transverse cracks at that area, $\mathrm{m} ; d_{S}$ is average distance between longitudinal cracks at that area, $\mathrm{m} ; d_{L}$ is the average distance between the reservoir cracks at that area, $\mathrm{m}$.

The volume of an artificial rectangular monolith (block) is determined by one of two equitation, the choice of which depends on the values of the average angles between the fracture systems:

$$
\begin{aligned}
& V_{u c \kappa}=L B H=\left(d_{S}-d_{L} \cdot \operatorname{ctg} \alpha_{S L}\right) \cdot\left(d_{Q}-d_{L} \cdot \operatorname{ctg} \alpha_{Q L}\right) \cdot d_{L}, \\
& V_{u c \kappa}=L B H=\left(d_{S}-d_{Q} \cdot \operatorname{ctg} \alpha_{S Q}\right) \cdot\left(d_{Q}-d_{L} \cdot \operatorname{ctg} \alpha_{Q L}\right) \cdot d_{L},
\end{aligned}
$$

where $L, B, H$ are monolith length, width and height, $\mathrm{m} ; \alpha_{S L}$ is the average angle between the system of longitudinal and reservoir cracks in the area, grad.; $\alpha_{Q L}$ is the average angle between the system of transverse and reservoir cracks in the area, grad.; $\alpha_{Q S}$ is average angle between the system of longitudinal and transverse cracks in the area, grad.

Such pairs of angles are selected that most incline the respective faces of natural separation, and the condition must be fulfilled. Equation (10) is used for $\alpha_{S L}<\alpha_{Q S}$, and (11) for $\alpha_{Q S}<\alpha_{S L}$.

With a known volume of an artificial rectangular monolith, it is possible to calculate the volumes and a number of commodity blocks, taking into account the losses associated with the equipment used for cutting:

$$
V_{\text {бл }}^{n}=\frac{V_{u с к}-\left[\left(N_{\text {бл.L }}-1\right) B+\left(N_{\text {бл.B }}-1\right) L\right] \cdot H b}{N_{\text {бл.L }} \cdot N_{\text {бл. } . \text { }}},
$$

where $n$ is the number of blocks into which the monolith is divided; $N_{\text {бл.L }}, N_{\text {бл.В }}$ are the number of blocks in length and width of the monolith; $b$ is crack width, which depends on the monolith cutting tool, on the roughness of the faces and requirements for the quality of the surface of the blocks, $\mathrm{m}$.

Formulas (10), (11), (12) can be effectively used with a parallelepiped form of natural separation with a maximum deviation of the average angles between cracks from perpendicularity of not more than $10^{\circ}$.

To confirm this and choose the optimal cutting scheme, we will consider a specific variant of modeling natural separation in the conditions of the Korninsky deposit of decorative granite (table 2).

The main parameters of natural separation (monolith) of the Korninsky decorative granite deposit

\begin{tabular}{|c|c|c|c|c|c|c|c|}
\hline$d_{S}, \mathbf{M}$ & $d_{Q}, \mathbf{M}$ & $d_{L}, \mathbf{M}$ & $\alpha_{Q S}$ & $\alpha_{S L}$ & $\alpha_{Q L}$ & $\begin{array}{c}V_{n p}, \\
\mathbf{M}^{\mathbf{3}}\end{array}$ & $\begin{array}{c}V_{u c k}, \\
\mathbf{m}^{\mathbf{3}}\end{array}$ \\
\hline 9,1 & 5,4 & 2,8 & $86^{\circ}$ & $81^{\circ}$ & $83^{\circ}$ & 137,592 & 122,553 \\
\hline
\end{tabular}

Mining operations at this quarry provide for the drilling and wedges technology for cutting monoliths. The cutting pattern of natural separation is shown in Fig. 1. 

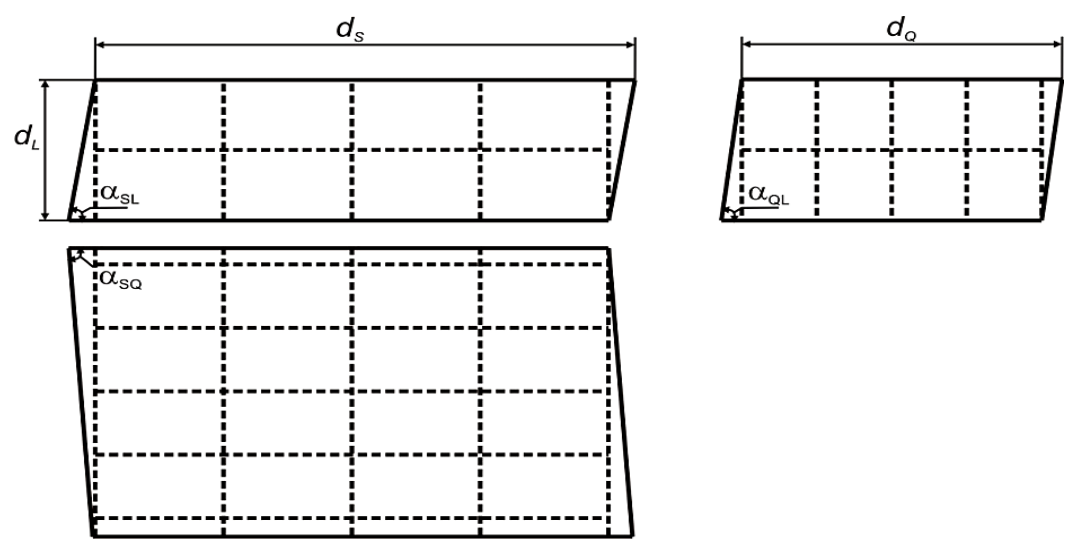

Fig. 1. The cutting pattern of parallelepiped natural separation into commercial blocks

We find the optimal cutting scheme using the proposed economic-mathematical model, which will have the following parameters: $N_{\text {бл.в }}\left(x_{1}, x_{2}, \ldots x_{n}\right), N_{\text {бл.L }}(1, n)$. As a result of the analysis of the $\mathrm{n}$-th number of schemes provided $x_{1}=1, x_{2}=2, x_{3}=3, x_{4}=4$, we get the dependence of the volumes of commercial blocks on their quantity using the drilling and wedges technology of cutting with $10 \mathrm{~cm}$ (Fig. 2).

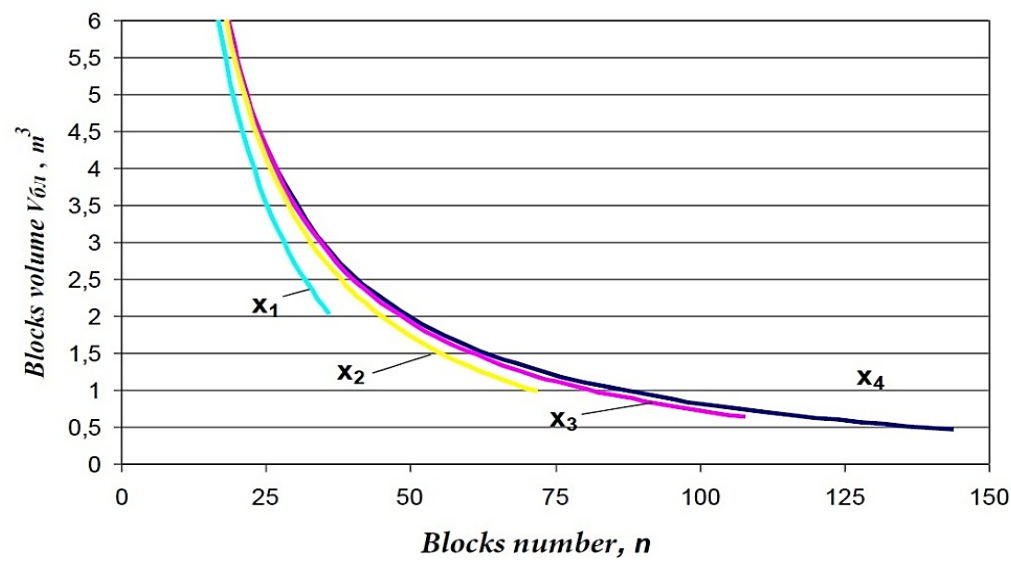

Fig. 2. The dependence of the volume of blocks $V_{б л}$ on their number $n$ in different schemes of cutting monolith

From fig. 2 we can see that the $x_{4}$ scheme is the most advantageous, since it allows you to get more blocks $n$ with the same volume $V_{б л}$. For example, a monolith cutting scheme $x_{4}$ will give 48 blocks with a volume of 2,08 $\mathrm{m}^{3}$, a scheme $x_{3}$ with 48 blocks with a volume of $2,01 \mathrm{~m}^{3}$, a scheme $x_{2}$ with 48 blocks with a volume of $1,82 \mathrm{~m}^{3}$, and a scheme $x_{1}$ with 48 blocks with a volume of $1,17 \mathrm{~m}^{3}$. A further increase in the number of blocks across the width of the monolith does not have a significant effect, therefore for the subsequent analysis we choose the $x_{4}$ scheme, which provides for $N_{б л . в}=4$.

To obtain the coordinates of the points of the commercial block, the subsequent construction of its three-dimensional model and determine the volume, it is proposed to use three methods and schemes for phototheodolite survey:

- $\quad$ surveying from four base points around the block and the direct serif method;

- $\quad$ surveying from two base points with the visibility of all faces of the block;

- $\quad$ surveying from one base point using a leveling rod and the visibility of two faces of the block.

It is possible to achieve a higher surveying efficiency and a smaller amount of geodetic calculations using a Bosch DLR-25 laser rangefinder with a measurement range of $25 \mathrm{~m}$ and an error of $2 \mathrm{~mm}$.

To substantiate the results of the methodology, studies were carried out, calculations in which and the development of the methodology relied on the required accuracy. The technique involves taking reports of horizontal angles and calculating the coordinates of a certain number of points on each side of the block, and all other coordinates are determined by interpolation with a certain step. The accuracy of determining the volume of a block depends on the accuracy of determining the coordinates of control points along the perimeter of the block and the accuracy of the interpolation method.

It is possible to use AutoCAD Civil3D as a software for building a model of a block using the known coordinates of its points, also for stereophotogrammetric processing of images that were obtained when surveying a block with a digital camera, you should use the Delta CFS. The latter allows you to take into account the distortion of the lens and the offset of the coordinates of the main point of the digital camera. The program determines the coordinates of the reference points on two or more images, taking into account the focal length of the camera and the basis of photographing. 
Digital surface model of granite block was created in Agisoft Photoscan (Fig. 3).
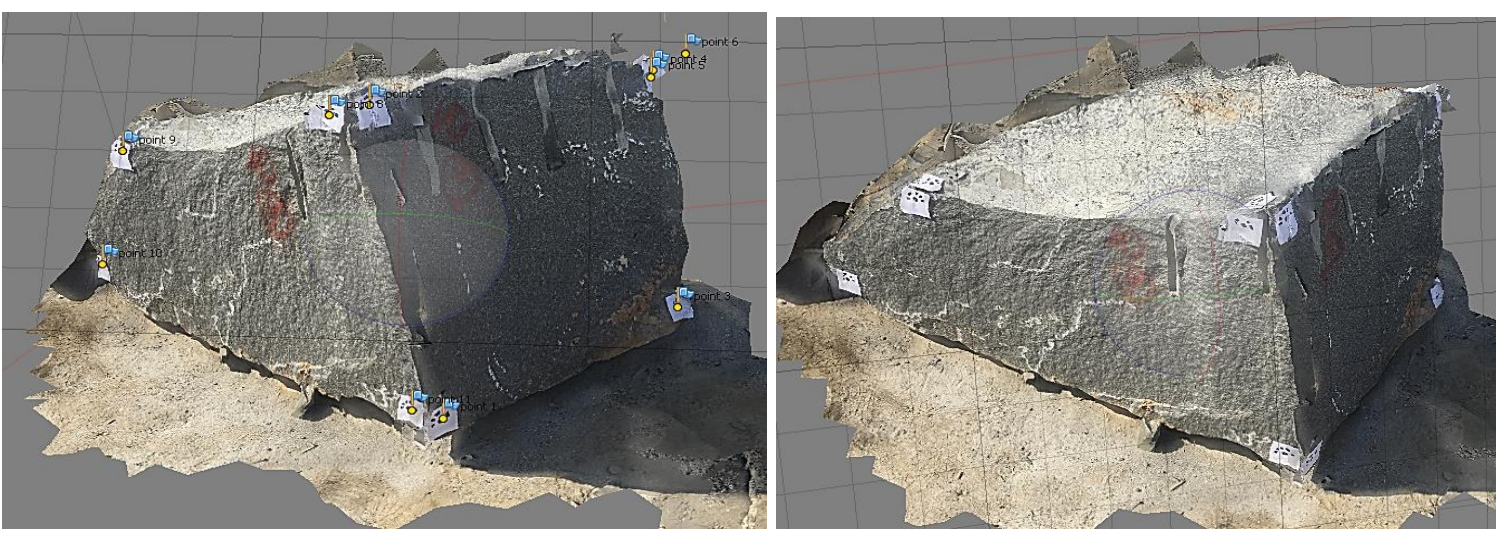

Fig. 3. DSM of granite block

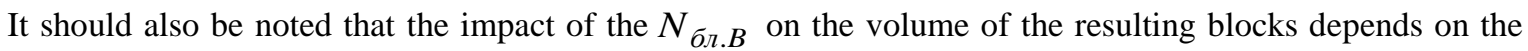
equipment for cutting the monolith i.e. the larger the gap width $b$, the larger the difference between the different cutting patterns. This is relevant since most quarries use drilling wedges technology for cutting, for which the value $b$ reaches $15 \mathrm{~cm}$.

Results. Taking into account the market price of Korninsky granite (table 3), we can rate the dependence of the mining enterprise profit on the number of commodity blocks of the respective category [3] and their volume in the drilling wedges cutting technology (Fig. 3, Fig. 4). This takes into account the price from the sale of a certain number of commercial blocks of the respective category and the cost of exposing $1 \mathrm{~m}^{2}$ of the surface of the massif by the drilling wedges method.

Table 3

Market prices for Korninsky granite deposit of different categories

\begin{tabular}{|c|c|c|c|c|c|c|}
\hline \multirow{2}{*}{ Parameter } & \multicolumn{7}{|c|}{ Block category } & VI \\
\cline { 2 - 7 } & I & II & III & IV & V & $<0,7$ \\
\hline $\begin{array}{c}\text { Volume of commercial } \\
\text { blocks } V_{\text {бл }}, \mathrm{m}^{3}\end{array}$ & $>5,01$ & $3,51-5,0$ & $2,01-3,5$ & $1,01-2,0$ & $0,71-1,0$ & 80 \\
\hline Block price $B, \$$ & 255 & 215 & 190 & 140 & 80 & 80 \\
\hline
\end{tabular}

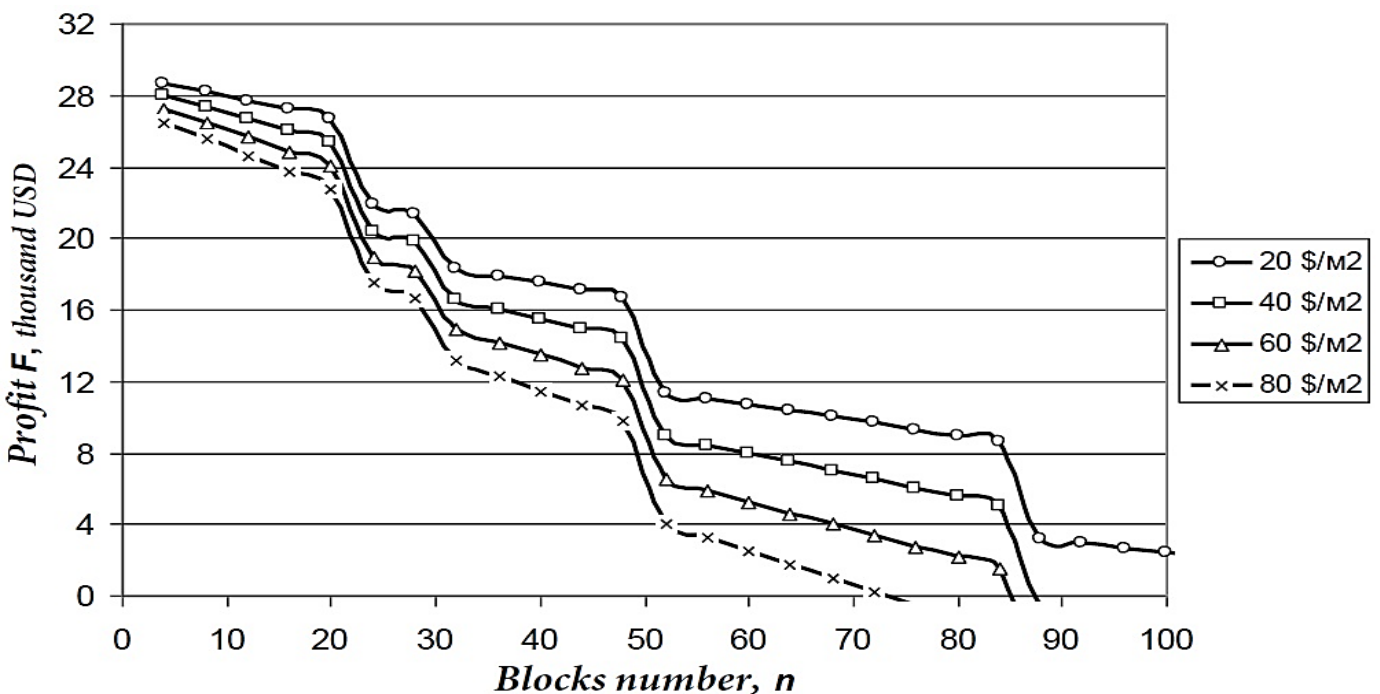

Fig. 4. Dependence of profit $F$ on the number of blocks $n$ at different costs for exposing $1 \mathrm{~m}^{2}$ of the rock deposit surface

Dependencies in Fig. 4 have a step-like shape due to the division of blocks by volume into 6 categories. The maximum profit in this case is obtained by extracting a smaller number of blocks, the volume of which increases accordingly. Considering the limitations on linear dimensions and weight of blocks given at the beginning of the article, we construct the dependence of the profit on the volume of blocks (Fig. 5). 


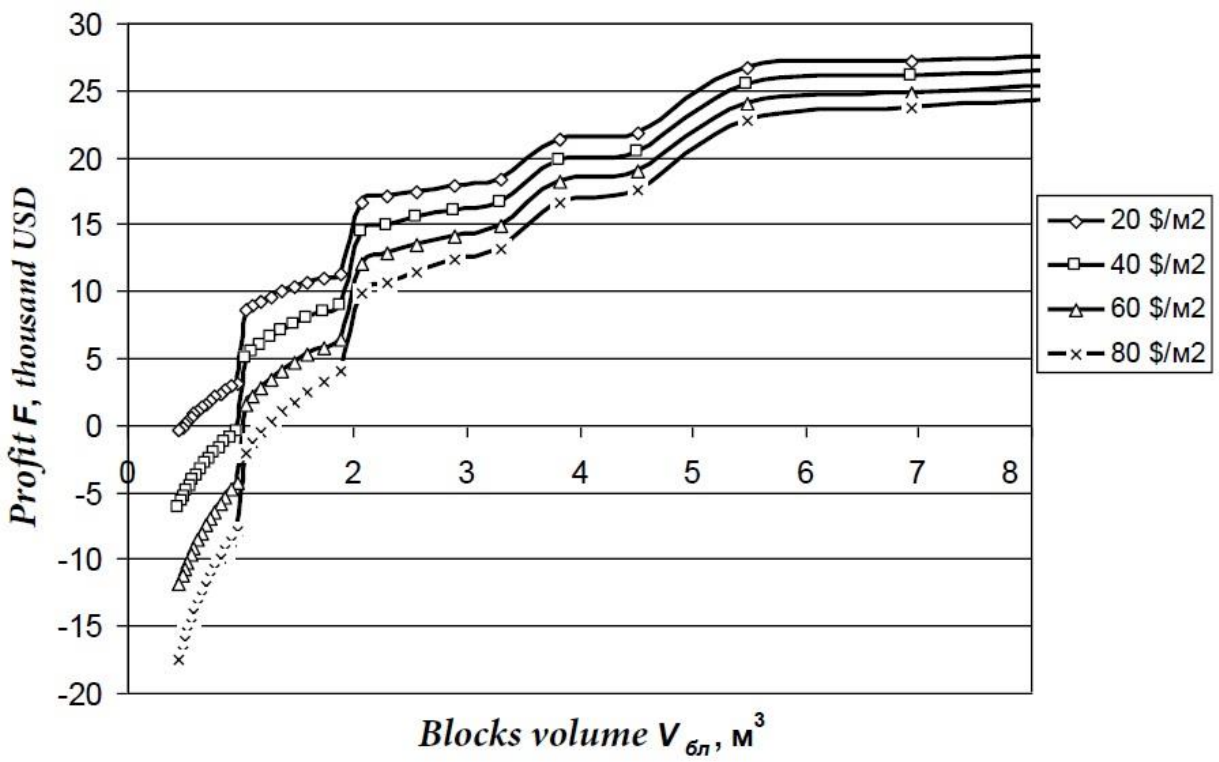

Fig. 5. Dependence of profit $F$ on the volume of blocks $V_{б л}$ at different costs for exposing $1 \mathrm{~m}^{2}$ of the array surface

Dependencies in Fig. 5 allow to make the following conclusions: 1) it is not profitable to produce blocks of up to $1 \mathrm{~m}^{3}$ (V-IV category); 2) the profit grows in proportion to the volume of blocks from $1 \mathrm{~m}^{3}$ to $5,5 \mathrm{~m}^{3} ; 3$ ) the extraction of blocks with a volume of more than $5,5 \mathrm{~m}^{3}$ does not give the expected increase in profit, therefore it is advisable to extract large blocks only for order or for export.

The optimal cutting scheme must be chosen with a view to the equipment that will be used for cutting the monolith, and the equipment with which the commercial block will be cut. Cutting monoliths into blocks of maximum sizes is not always an effective and economically convenient option, that is why the cutting scheme needs to be coordinated with the processing enterprise, taking into account the product range and technical parameters of the processing equipment. This will allow minimizing losses in both excavation and further processing with natural stone.

In this case, the optimal scheme for cutting the natural separation of volume $V_{б л}=137,592 \mathrm{~m}^{3}$ of the Korninsky granite deposit is cutting it into 20 blocks $\left(N_{б л . L}=5, N_{б л . В}=4\right)$ of 5,48 $\mathrm{m}^{3}$ each, at which the maximum profit of the quarry reaches about 27 thousand dollars.

Conclusions. The problem of modeling optimal cutting scheme can be solved in the presence of the size of natural entities and their shape, which are quite difficult to obtain with direct measurement methods in a quarry. Therefore, the current state of the stone mining industry requires the introduction of remote sensing methods, which include digital ground-based photogrammetric survey. With the help of the latter, it is possible to create surveying documentation i.e. basic information for modeling and analyzing natural separation, determine the geometric dimensions of natural separation on the basis of digital images and draw up an optimal cutting scheme using them, using the above method and economic and mathematical model.

For surveying support of dimension stone quarries, namely, keeping accounting logs and passports of commercial blocks, it is recommended to use the first survey method from four base points, as the most accurate and effective. One of the rational ways to increase the speed of surveying and processing its results is the additional use of a laser rangefinder.

Further studies in this direction include a multifactor analysis of the process of cutting monoliths by different technological complexes, taking into account the subsequent processing stage and the optimal configuration schemes for cutting rates. This will allow to fully automate and predict the maximum yield of finished products at the stage of natural separation based on the processing of digital images taken directly in the face of the current mining operations.

\section{Список використаної літератури:}

1. Бакка Н.T. Облицовочный камень. Геолого-промышленная и технологическая оценка месторождений : справочник / Н.Т. Бакка, И.В. Ильченко. - М. : Недра, 1992. - 303 с.

2. Бакка Н.T. Добыча и обработка природного камня / Н.Т. Бакка, А.Г. Смирнов. - М. : Недра, 1990. -445 с.

3. Бобир Н.Я. Фотограмметрия / Н.Я. Бобир, А.Н. Лобанов, Г.Д. Федорук. - М. : Недра, 1974. - 472 с.

4. Гельман Р.Н. Влияние размера пикселя на точность измерений цифрового снимка и построения модели / Р.Н. Гельман // Геодезия и картография. - № 9. - 2004. - С. 35-37.

5. Долгіх Л.В. Практика використання цифрових методів зйомки кар'єрів / Л.В. Долгіх // Вісник КТУ. - Кривий Ріг : КТУ. - 2007. - Вип. 16. - С. 44-48. 
6. Долгіх Л.В. Сучасні методи знімальних робіт на кар'єрах / Л.В. Долгіх, О.В. Долгіх, М.М. Малецький // Вісник КТУ. - Кривий Ріг : КТУ. - 2006. - Вип.13. - С. 48-51.

7. Levytskyi $V$. The new approach of using image and range based methods for quality control of dimension stone / V.Levytskyi // Reports on Geodesy and Geoinformatics. The Journal of Warsaw University of Technology. - 2017. Vol. 103/2017. - Pp. 66-77.

8. Книжников Ю.Ф. Зависимость точности стереоскопических измерений от размера пикселя цифрових снимков / Ю.Ф. Книжников // Геодезия и картография. - 2003. - № 4. - С. 32-41.

9. Levytskyi $\mathrm{V}$. The optimization of technological mining parameters in quarry for dimension stone blocks quality improvement based on photogrammetric techniques of measurement / V.Levytskyi, R.Sobolevskyi, V.Korobiichuk // The Mining-Geology-Petroleum Engineering Bulletin. - 2018. - Vol. 33 (2), No. 40, Pp. 83-90.

10. Лобанов А.Н. Фотограмметрия / А.Н. Лобанов. - 2-е изд., перераб. и доп. - М. : Недра, 1984. - 552 с.

11. Аналитическая пространственная фототриангуляция / А.Н. Лобанов, В.Б. Дубиновский, М.М. Машимов, Р.П. Овсянников. - М. : Недра, 1991. - 255 с.

12. Фотограмметрия / С.Г. Могильный, И.Л. Беликов, Л.И. Ахонина, Д.В. Брежнев, М.П. Бордюков. - КиевДонецк : Вища школа, 1985. - 278 с.

13. Сердюков B.M. Фотограмметрия в промышленном и гражданском строительстве / В.M. Сердюков. - М. : Недра, 1977. - 245 с.

14. Синельников О.Б. Природный облицовочный камень. Ч. І / О.Б. Синельников. - Облицовочные камни: Учебное пособие. - М. : МГГУ, 2000. - 362 с.

15. Федоренко П.И. Использование цифровых методов фотограмметрии для маркшейдерского обеспечения карьеров / П.И. Федоренко, Л.В. Долгих, А.В. Долгих // Разработка рудных месторождений. - Кривой Рог : КТУ. - № 85. - 2004. - С. 59-62.

16. Чибуничев А.Г. О возможностях применения цифровых методов фотограмметрии для решения инженерных задач / А.Г. Чибуничев // Известия вузов. Геодезия и аэрофотосъемка. - 1990. - № 6. - С. 76-82.

17. Rock mass structural data analysis using image processing techniques (Case study: Choghart iron ore mine northern slopes) / M.Mohebbi, A.R. Yarahmadi Bafghi, M.Fatehi Marji, J.Gholamnejad // Journal of Mining \& Environment. Vol. 8 (1). - Pp. 61-74.

18. Turanboy A. A new approach to rapid 3D mapping of rock mass structure. - Geotechnical Engineering. - 2010. Vol. 163 6). - Pp. 321--331.

19. Development of an all-purpose free photogrammetric tool / D.González-Aguilera, L.López-Fernández, P.RodriguezGonzalvez, D.Guerrero, D.Hernandez-Lopez, F.Remondino, F.Menna, E.Nocerino, I.Toschi, A.Ballabeni, M.Gaiani // The International Archives of the Photogrammetry, Remote Sensing and Spatial Information Sciences. - 2016 Vol. 41 (B6). - Pp. 31-38.

20. Cluster analysis of fracturing in the deposits of decorative stone for the optimization of the process of quality control of block raw material / R.Sobolevskyi, N.Zuievska, V.Korobiichuk, O.Tolkach, V.Kotenko // Eastern-European Journal of Enterprise Technologies. - 2016. - Vol. 5 (83). - Pp. 21-29.

21. Sobolevskyi $R$. Evaluation of accuracy of photogrammetric methods and laser scanning for measuring of parameters of cracks natural separateness / R.Sobolevskyi, V.Levytskyi, V.Shlapak // The Journal of Zhytomyr State Technological University, Series Engineering. - 2016. - Vol. 1 (76). - Pp. 158-164.

22. A procedure for modeling the deposits of kaolin raw materials based on the comprehensive analysis of quality indicators / R.Sobolevskyi, O.Vaschuk, O.Tolkach, V.Korobiichuk, V.Levytskyi // Eastern-European Journal of Enterprise Technologies. - Vol. 3/3 (87). - Pp. 54-66.

23. Levytskyi $V$. Decorative stone block quality control based on surface digital photogrammetry / V.Levytskyi, R. Sobolevskyi // Scientific Bulletin of National Mining. - 2014. - Vol. 6. - Pp. 58-66.

24. Definition of hue of different types of pokostivskiy granodiorite using digital image processing / V.Korobiichuk, V.Shamrai, O.Iziumova, O.Tolkach, R.Sobolevskyi // Eastern-European Journal of Enterprise Technologies. - 2016. Vol. 4 (5). - Pp. 52-57.

25. Panasiuk A. Analysis of fractal characteristics of mining and geological parameters of minerals / A.Panasiuk, V.Bondarchuck // Metallurgical and Mining Industry. - 2016. - Vol. 10. - Pp. 42-45.

\section{References:}

1. Bakka, N.T. and Il'chenko, I.V. (1992), Oblitsovochnyy kamen'. Geologo-promyshlennaya i tekhnologicheskaya otsenka mestorozhdeniy, Spravochnik, Nedra, M., 303 p.

2. Bakka, N.T. and Smirnov, A.G. (1990), Dobycha i obrabotka prirodnogo kamnya, Nedra, M., 445 p.

3. Bobir, N.Ya., Lobanov, A.N. and Fedoruk, G.D. (1974), Fotogrammetriya, Nedra, M., 472 p.

4. Gel'man, R.N. (2004), «Vliyanie razmera pikselya na tochnost' izmereniy tsifrovogo snimka i postroeniya modeli», Geodeziya i kartografiya, No. 9, Pp. 35-37.

5. Dolgih, L.V. (2007), «Praktyka vykorystannja cyfrovyh metodiv zjomky kar'jeriv», Visnyk KTU, KTU, Kryvyj Rig, Iss. 16 , Pp. 44-48.

6. Dolgih, L.V., Dolgih O.V. and Malec'kyj, M.M. (2006), «Suchasni metody znimal'nyh robit na kar'jerah», Visnyk $K T U$, KTU, Kryvyj Rig, Iss. 13, Pp. 48-51.

7. Levytskyi, V. (2017), «The new approach of using image and range based methods for quality control of dimension stone», Reports on Geodesy and Geoinformatics. The Journal of Warsaw University of Technology, Vol. 103/2017, Pp. 66-77.

8. Knizhnikov, Yu.F. (2003), «Zavisimost' tochnosti stereoskopicheskikh izmereniy ot razmera pikselya tsifrovikh snimkov», Geodeziya i kartografiya, No. 4, Pp. 32-41. 
9. Levytskyi, V., Sobolevskyi, R. and Korobiichuk, V. (2018), «The optimization of technological mining parameters in quarry for dimension stone blocks quality improvement based on photogrammetric techniques of measurement», The Mining-Geology-Petroleum Engineering Bulletin, Vol. 33 (2), No. 40, Pp. 83-90.

10. Lobanov, A.N.(1984), Fotogrammetriya, $2^{\text {nd }}$ izd., pererab. i dop., Nedra, M., 552 p.

11. Lobanov, A.N., Dubinovskiy, V.B., Mashimov, M.M. and Ovsyannikov, R.P. (1991), Analiticheskaya prostranstvennaya fototriangulyatsiya, Nedra, M., $255 \mathrm{p}$.

12. Mogil'nyy, S.G., Belikov, I.L., Akhonina, L.I., Brezhnev, D.V. and Bordyukov, M.P. (1985), Fotogrammetriya, Vishcha shkola, Kiev-Donetsk, 278 p.

13. Serdyukov, V.M. (1977), Fotogrammetriya v promyshlennom i grazhdanskom stroitel'stve, Nedra, M., 245 p.

14. Sinel'nikov, O.B. (2000), Prirodnyy oblitsovochnyy kamen'. P. I., Oblitsovochnye kamni, MGGU, M., 362 p.

15. Fedorenko, P.I., Dolgikh, L.V. and Dolgikh, A.V. (2004), «Ispol'zovanie tsifrovykh metodov fotogrammetrii dlya marksheyderskogo obespecheniya kar'erov», Razrabotka rudnykh mestorozhdeniy, KTU, Krivoy Rog, No. 85, Pp. 59-62.

16. Chibunichev, A.G. (1990), «O vozmozhnostyakh primeneniya tsifrovykh metodov fotogrammetrii dlya resheniya inzhenernykh zadach», Izvestiya vuzov. Geodeziya i aerofotos"emka, No. 6, Pp. 76-82.

17. Mohebbi, M., Yarahmadi Bafghi, A.R., Fatehi Marji, M. and Gholamnejad, J. (2017), «Rock mass structural data analysis using image processing techniques (Case study: Choghart iron ore mine northern slopes)», Journal of Mining \& Environment, Vol. 8 (1), Pp. 61-74.

18. Turanboy, A. and Ülker, E. (2010), «A new approach to rapid 3D mapping of rock mass structure», Geotechnical Engineering, Vol. 163 (6), Pp. 321-331.

19. González-Aguilera, D., López-Fernández, L., Rodriguez-Gonzalvez, P., Guerrero, D., Hernandez-Lopez, D., Remondino, F., Menna, F., Nocerino, E., Toschi, I., Ballabeni, A. and Gaiani, M. (2016), «Development of an allpurpose free photogrammetric tool», The International Archives of the Photogrammetry, Remote Sensing and Spatial Information Sciences, Vol. 41 (B6), Pp. 31-38.

20. Sobolevskyi, R., Zuievska, N., Korobiichuk, V., Tolkach, O. and Kotenko, V. (2016), «Cluster analysis of fracturing in the deposits of decorative stone for the optimization of the process of quality control of block raw material», Eastern-European Journal of Enterprise Technologies, Vol. 5 (83), Pp. 21-29.

21. Sobolevskyi, R., Levytskyi, V. and Shlapak, V., (2016), «Evaluation of accuracy of photogrammetric methods and laser scanning for measuring of parameters of cracks natural separateness», The Journal of Zhytomyr State Technological University, Series Engineering, Vol. 1 (76), Pp. 158-164.

22. Sobolevskyi, R., Vaschuk, O., Tolkach, O., Korobiichuk, V. and Levytskyi, V. «A procedure for modeling the deposits of kaolin raw materials based on the comprehensive analysis of quality indicators», Eastern-European Journal of Enterprise Technologies, Vol. 3/3 (87), Pp. 54-66.

23. Levytskyi, V. and Sobolevskyi, R. (2014), «Decorative stone block quality control based on surface digital photogrammetry», Scientific Bulletin of National Mining, Vol. 6, Pp. 58-66.

24. Korobiichuk, V., Shamrai, V., Iziumova, O., Tolkach, O. and Sobolevskyi, R. (2016), «Definition of hue of different types of pokostivskiy granodiorite using digital image processing», Eastern-European Journal of Enterprise Technologies, Vol. 4 (5), Pp. 52-57.

25. Panasiuk, A. and Bondarchuck, V. (2016), «Analysis of fractal characteristics of mining and geological parameters of minerals», Metallurgical and Mining Industry, Vol. 10, Pp. 42-45.

Levytskyi Volodymyr - Ph.D., Associate Professor of Mine Surveying Department of Zhytomyr State Technological University.

Scientific interests:

- mining;

- mine surveying;

- photogrammetry;

- construction materials.

Makhno Artur - M.S. of Mine Surveying Department of Zhytomyr State Technological University.

Scientific interests:

- mining;

- mine surveying;

- photogrammetry;

- construction materials.

Panasiuk Andrii - Ph.D., Associate Professor of Mine Surveying Department of Zhytomyr State Technological University.

Scientific interests:

- mining;

- mine surveying;

- construction materials.

Mamrai Vasyl - M.S. of Mine Surveying Department of Zhytomyr State Technological University.

Scientific interests:

- mining;

- mine surveying. 